\title{
SPALLOGENIC ${ }^{14} \mathrm{C}$ IN HIGH-ALTITUDE ROCKS AND IN ANTARCTIC METEORITES
}

\author{
A J T JULL, D J DONAHUE, T W LINICK \\ NSF Accelerator Facility for Radioisotope Analysis \\ University of Arizona, Tucson, Arizona 85721 \\ and \\ G C WILSON \\ Turnstone Geological Services Ltd, P O Box 130 \\ Station B, Toronto, Ontario, Canada M5T 2T3
}

\begin{abstract}
C}$ in high-altitude rocks and in Antarctic meteorites of long terrestrial age has been found at levels consistent with in-situ production by cosmic rays. Levels of $0.2-0.59 \mathrm{dpm} /$ $\mathrm{kg}$ (or $1.0-2.6 \times 10^{6}{ }^{14} \mathrm{C} / \mathrm{g}$ ) are found in high-altitude samples ranging from 3300 to $5460 \mathrm{~m}$. Similar values are observed in Antarctic meteorites that have been dated by ${ }^{81} \mathrm{Kr}$ by Freundel, Schultz \& Reedy (1986) as over 100 kyr old.
\end{abstract}

\section{INTRODUCTION}

Cosmic rays interact with the surface of the earth as well as its atmosphere and with objects such as meteorites in space. Due to the rapid attenuation of high-energy particles in the atmosphere, the surface flux of highenergy neutrons is 2 to 3 orders of magnitude below the free-space level (Lal $\&$ Peters, 1967). Until recently, cosmogenic ${ }^{14} \mathrm{C}$ has only been determined in meteorites of terrestrial age $<30 \mathrm{kyr}$ (Goel \& Kohman, 1962; Suess \& Wänke 1962; Born \& Begemann, 1975; Boeckl, 1972; Fireman, 1978, 1979, 1983). Begemann et al (1972), Fireman, DeFelice and D'Amico (1976) and Fireman (1978) also studied lunar samples. Levels of ${ }^{14} \mathrm{C}$ in some older meteorites from Antarctica have been detected down to ca $1 \mathrm{dpm} / \mathrm{kg}$ (Jull et al, 1984; Brown et al, 1984; Beukens, Rucklidge \& Miura, 1988). The levels determined in these samples are higher than expected from production alone (Yokoyama, Reyss \& Guichard, 1977) and warrant further investigation. Sample sizes have been reduced to $<1 \mathrm{~g}$ (Jull \& Donahue, 1988; Beukens, Rucklidge \& Miura, 1987) from the $\sim 10 \mathrm{~g}$ required earlier. The enhanced sensitivity of accelerator mass spectrometry (AMS) and reduced blank levels have now allowed us to investigate cosmic-ray spallation ${ }^{14} \mathrm{C}$ in high-altitude terrestrial rocks, as well as in some Antarctic meteorites, where all extraterrestrial ${ }^{14} \mathrm{C}$ has decayed (Jull, Donahue \& Linick, 1989). Studies of other "in-situ-produced" isotopes, such as ${ }^{10} \mathrm{Be}$ and ${ }^{36} \mathrm{Cl}$ in Libyan desert glass (Klein et al, 1986, Lal, 1987) and high-altitude rocks (Phillips et al, 1986; Leavy et al, 1986), indicate reasonable agreement with theoretical predictions (Lal, 1987; Yokoyama, Reyss \& Guichard, 1977). If these levels can be established, the potential of dating surfaces by studying the levels of cosmic-ray-produced radionuclides may be realistic. This paper presents results of an initial study of cosmogenic ${ }^{14} \mathrm{C}$ in terrestrial rocks. A companion study of ${ }^{14} \mathrm{C}$ in rocks using acid extraction techniques will be 
reported elsewhere (Lal, Jull \& Donahue, unpub results).

\section{THE SAMPLES}

Available mineralogic data for the terrestrial sample suite are summarized in Table 1. Seven samples were analyzed, of which 3 are granitic plutonic rocks, 3 are intermediate volcanics, and 1 (the Herkimer quartz) is a sub-surface "control sample" from a location noted for clear quartz (Sinkankas, 1976). The volcanic suite are surface "grab samples" from the upper slopes of three major volcanoes in east-central Mexico: Popocatepetl, La Malinche, and Citlaltepetl, alias Pico de Orizaba (hereafter "Orizaba").

TABLE 1

Composition of the terrestrial samples

\begin{tabular}{llll}
\hline Sample & Rock type & Major minerals & Minor minerals \\
\hline 003 & Biotite granite & $\begin{array}{l}\text { Plagioclase, K-feldspar, } \\
\text { quartz, biotite }\end{array}$ & $\begin{array}{l}\text { Myrmekite, oxide, } \\
\text { apatite, zircon, epidote, } \\
\text { chlorite (2) }\end{array}$ \\
099 & Porphyritic andesite & $\begin{array}{l}\text { Glass, plagioclase, } \\
\text { oxides after amphibole }\end{array}$ & Amphibole (Trace) \\
090 & Porphyritic andesite & Glass, plagioclase & Orthopyroxene, \\
& & & $\begin{array}{l}\text { clinopyroxene, } \\
\text { sulphides (5) }\end{array}$ \\
304 & Porphyritic andesite & $\begin{array}{l}\text { Plagioclase, glass, } \\
\text { amphibole }\end{array}$ & $\begin{array}{l}\text { Clinopyroxene, } \\
\text { oxides (Trace) }\end{array}$ \\
SMTP-1 & Granodiorite & - & - \\
D-1 & Granodiorite & - & - \\
Q2A & Quartz & Quartz & - \\
\hline
\end{tabular}

Where petrographic data are available, the constituent minerals of the samples are listed in decreasing order of abundance (based on estimated volume percent). The 'minor' minerals are present in total amounts varying from trace to $5 \%$.

\section{EXPERIMENTAL}

A sample of $0.5-2 \mathrm{~g}$ rock is ground up, mixed with ca $2-4 \mathrm{~g}$ ironaccelerator chips as a combustion flux, and placed in a low-carbon crucible. The samples are placed in a muffle furnace for $1 \mathrm{hr}$ at $500^{\circ} \mathrm{C}$ to remove contaminants. The sample/iron mix is then placed in the RF extraction furnace and heated to fusion for up to $8 \mathrm{~min}$ in a flow of oxygen. The oxygen is flushed through the system every 1-2 min and collected in a liquid-nitrogen trap, after passing through a dust trap, $\mathrm{MnO}_{2}$ and a $\mathrm{CuO} / \mathrm{Pt}$ furnace at $500^{\circ} \mathrm{C}$. After heating, the $\mathrm{O}_{2}$ is pumped away, and the remaining $\mathrm{CO}_{2}$ is separated from water by distillation at $-78^{\circ} \mathrm{C}$. The amount of $\mathrm{CO}_{2}$ is measured, giving an estimate of the $\mathrm{C}$ content of the sample, and is then diluted to 1-2cc STP $\mathrm{CO}_{2}$ with ${ }^{14} \mathrm{C}$ "dead" gas. The diluted $\mathrm{CO}_{2}$ is reduced to graphite over iron (Slota et al, 1987). The resultant graphite powder is 
pressed into an accelerator target holder and mounted in a 10-position wheel along with 2 standards, normally NBS oxalic acids I and II. The methods used for accelerator measurement of ${ }^{14} \mathrm{C}$ have been described in detail by Linick et al (1986).

\section{RESULTS AND DISCUSSION}

$\mathrm{CO}_{2}$ was extracted from several high-altitude rocks as a test study of insitu production of ${ }^{14} \mathrm{C}$ by cosmic-ray spallation. The fraction released at temperatures above $500^{\circ} \mathrm{C}$ gives a reliable measure of the spallogenic $\mathrm{C}$ content (Desmarais, 1983; Jull \& Donahue, 1988; Jull, Donahue \& Linick, 1989). As discussed, the $500^{\circ} \mathrm{C}$ preheating step removes low-temperature weathering products and other contaminants, with the exception of calcite. Results are shown in Table 2. The data shown are given both corrected and uncorrected for the extraction system blank of $(8 \pm 1) \times 10^{5}{ }^{14} \mathrm{C}$. This blank mainly results from residual ${ }^{14} \mathrm{C}$ memory in the extraction line, which has also been used for meteorites. The levels shown in Table 2 are given in $\mathrm{dpm} / \mathrm{kg}$ to facilitate direct comparison with the production rates, such as those calculated by Yokoyama, Reyss \& Guichard (1977), which are proportional to the cut-off rigidity, a function of geomagnetic latitude (Shea $e t$ $a l$, 1987). The data are compared in Figure 1, including some additional data from three Antarctic meteorites. These three samples were dated by

TABLE 2

${ }^{14} \mathrm{C}$ content of high-altitude rocks

\begin{tabular}{|c|c|c|c|c|c|c|c|}
\hline Sample & Site & Altitude & $\begin{array}{c}\text { Geomagnetic } \\
\text { latitude }\end{array}$ & $\begin{array}{c}\text { Fraction } \\
\text { modern }{ }^{14} \mathrm{C}\end{array}$ & $\mathrm{cc} \mathrm{CO}_{2}{ }^{*}$ & $\begin{array}{l}{ }^{14} \mathrm{C} \mathrm{dpm} / \\
\text { Uncorrected }\end{array}$ & $\mathrm{kg}_{\text {Corrected }}$ \\
\hline \multirow[t]{2}{*}{$\overline{003}$} & $\begin{array}{l}\text { Mt Massive, } \\
\text { Colorado, 2.06g }\end{array}$ & $4396 \mathrm{~m}$ & $49^{\circ} \mathrm{N}$ & $0.0561 \pm 0.002$ & 2.24 & $0.41 \pm 0.01$ & $0.31 \pm 0.03$ \\
\hline & $\begin{array}{l}\text { Mt Massive, } \\
\text { Colorado, } 0.945 \mathrm{~g}\end{array}$ & & & $0.054 \pm 0.002$ & 1.63 & $0.49 \pm 0.02$ & $0.34 \pm 0.03$ \\
\hline 299 & $\begin{array}{l}\text { La Malinche, } \\
\text { Mexico, } 0.945 \mathrm{~g}\end{array}$ & $4461 \mathrm{~m}$ & $28^{\circ} \mathrm{N}$ & $0.088 \pm 0.002$ & 1.75 & $1.08 \pm 0.03$ & $0.55 \pm 0.04$ \\
\hline 090 & $\begin{array}{l}\text { Popocatepetl, } \\
\text { Mexico, 1.107g }\end{array}$ & $5452 \mathrm{~m}$ & $28^{\circ} \mathrm{N}$ & $0.087 \pm 0.006$ & 1.46 & $0.76 \pm 0.05$ & $0.59 \pm 0.05$ \\
\hline 304 & $\begin{array}{l}\text { Orizaba, } \\
\text { Mexico, } 1.055 \mathrm{~g}\end{array}$ & $4270 \mathrm{~m}$ & $28^{\circ} \mathrm{N}$ & $0.045 \pm 0.002$ & 1.53 & $0.43 \pm 0.01$ & $0.25 \pm 0.03$ \\
\hline SMTP-1 & $\begin{array}{l}\text { Mt Morgan, } \\
\text { California, } 1.454 \mathrm{~g}\end{array}$ & $4000 \mathrm{~m}$ & $43^{\circ} \mathrm{N}$ & $0.050 \pm 0.002$ & 1.85 & $0.42 \pm 0.02$ & $0.29 \pm 0.02$ \\
\hline D-1 & $\begin{array}{l}\text { White Mts } \\
\text { California, } 1.698 \mathrm{~g}\end{array}$ & $3300 \mathrm{~m}$ & $46^{\circ} \mathrm{N}$ & $0.110 \pm 0.003$ & 0.90 & $0.39 \pm 0.01$ & $0.27 \pm 0.02$ \\
\hline $\begin{array}{l}\text { Blank: } \\
\text { Q2A }\end{array}$ & $\begin{array}{l}\text { Herkimer, } \\
\text { New York, } 0.967 \mathrm{~g}\end{array}$ & $\mathrm{~N} / \mathrm{A}$ & $52^{\circ} \mathrm{N}$ & $0.020 \pm 0.002$ & 1.20 & $0.16 \pm 0.02$ & $<0.04$ \\
\hline
\end{tabular}

${ }^{*}$ At $25^{\circ} \mathrm{C}$ 


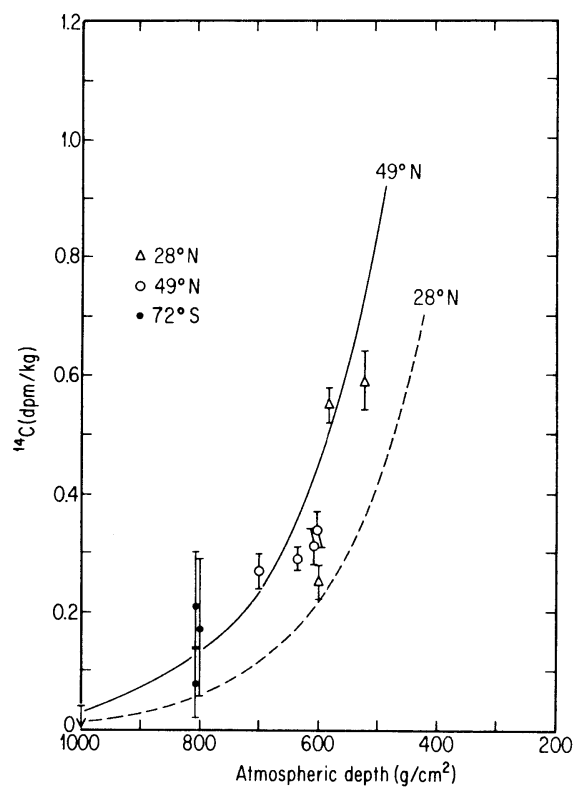

Fig $1 .{ }^{14} \mathrm{C}(\mathrm{dpm} / \mathrm{kg})$ measured in rocks of different altitude (plotted as atmospheric depth in $\left.\mathrm{g} / \mathrm{cm}^{2}\right)$ and geomagnetic latitude

${ }^{81} \mathrm{Kr}$ (Freundel, Schultz \& Reedy, 1986) as having a terrestrial age $>100 \mathrm{kyr}$, so no extraterrestrial ${ }^{14} \mathrm{C}$ from irradiation in space should be present. The error bars on the meteorite samples are larger due to the smaller sample size $(0.5-0.7 \mathrm{~g})$ used in these extractions, which were reported in detail (Jull, Donahue \& Linick, 1988). The three meteorites plotted are Allan Hills 78132, Pecora Escarpment 82502, and Elephant Moraine 79005, which had ${ }^{14} \mathrm{C}$ contents of $0.21 \pm 0.09,0.08 \pm 0.06$ and $0.17 \pm 0.11 \mathrm{dpm} / \mathrm{kg}$, respectively (Jull \& Donahue, 1988; Jull, Donahue \& Linick, 1989). Values from two granitoid samples (003 and SMTP-1) plot very well when compared to the curves estimated from the data of Yokoyama, Reyss \& Guichard, 1977), as does andesite sample 090 from Mexico. A granitic sample, from the White Mountains of California, with a desert varnish age of ca 10,000 yr (Dorn, pers commun) plots close to the $40^{\circ} \mathrm{N}$ curve from the data of Yokoyama, Reyss and Guichard (1977). However, if the desert varnish age is correct, the sample ought to be only $70 \%$ saturated in ${ }^{14} \mathrm{C}$. The variation in the Mexican samples is almost certainly due to the young ages of some of these volcanic rocks. Sample 304 from Orizaba may be undersaturated, compared to the other samples. The latest phase of volcanism on Orizaba, in which much of the upper parts of the volcano have been constructed, occurred during the past 13,000 yr (Negendank et al, 1985). An age of 13,000 yr would give a value of ca $80 \%$ of saturation for ${ }^{14} \mathrm{C}$. The Antarctic meteorite data also seem to fit the curve reasonably well, with large errors. Of course, these comparisons assume that the estimates made by Yokoyama, Reyss and Guichard (1977) are reasonable. The theoretical values of these authors rely on a few measurements of ${ }^{22} \mathrm{Na}$ and ${ }^{24} \mathrm{Na}$ in samples of metal from man- 
made objects exposed at altitudes of $2070-4600 \mathrm{~m}$ in France (Yokoyama, Reyss \& Guichard, 1977). Extrapolation of the production rates to other isotopes assumes knowledge of the relative cross-sections and also of the attenuation of high-energy cosmic-ray particles in the atmosphere. In the case of ${ }^{14} \mathrm{C}$, the cross-section for neutron spallation is assumed to be similar to that of protons (Reedy \& Arnold, 1972) above a few hundred MeV, with some assumptions about the excitation function in the range $50-200 \mathrm{MeV}$ (Reedy \& Arnold, 1972). Yokoyama, Reyss and Guichard (1977) assume the atmosphere attenuates high-energy particles with depth (in $\mathrm{g} / \mathrm{cm}^{2}$ ) similar to the lunar surface, for which the best profile data are available, and a mean attenuation length of $192 \pm 5 \mathrm{~g} / \mathrm{cm}^{2}$ was used, rather larger than the $118 \mathrm{~g} / \mathrm{cm}^{2}$ used by Reedy \& Arnold (1972) in their calculations on lunar cores. No geological evidence of erosion was observed in the samples studied. As has been discussed by Klein et al (1986), in the case of ${ }^{10} \mathrm{Be}$, the effects of erosion would reduce the total concentration of ${ }^{14} \mathrm{C}$. However, if the erosion is very low, as expected for these rock samples, the effects on radionuclides such of ${ }^{14} \mathrm{C}$ will be negligible, as is also the case for the ${ }^{36} \mathrm{Cl}$ samples studied by Leavy et al (1987).

\section{CONCLUSIONS}

The first measurements of spallogenic ${ }^{14} \mathrm{C}$ in terrestrial rocks, and in some Antartic meteorites, are reported. The results seem to indicate fair-togood agreement with theoretical calculations (Lal, 1987; Yokoyama, Reyss \& Guichard, 1977). In some samples, the complicating effects of a possible low rock age may result in undersaturation. If good saturated activity or production rate curves can be established for different latitudes and altitudes, then a reasonable chronology for dating of rock surfaces can be established. This will be of great benefit to geomorphology, which relies heavily on proxy estimates of age at present.

\section{ACKNOWLEDGMENTS}

We thank L J Toolin, A Hatheway, B H Gore and P J Sercel for technical assistance in the accelerator laboratory. We thank Ronald Dorn (Texas Technical University, Lubbock, Texas) and Fred Phillips (New Mexico Institute of Mining and Mineral Technology, Socorro, New Mexico) for provision of samples, and D Lal (University of California, San Diego) for helpful advice and discussions. GCW thanks assorted compañeros for support in the collection of the Mexican sample suite. This work was funded by NASA grant NAG 9-233 and NSF grant EAR 85-12761.

\section{REFERENCES}

Begemann, F, Born, W, Palme, H, Vilcsek, E and Wänke, H, 1972, Cosmic-ray produced radioisotopes in Apollo 12 and 14 samples: Proc Lunar Sci conf, 3rd, p 1693-1702.

Beukens, R P, Rucklidge, J C and Miura, Y, 1988, ${ }^{14} \mathrm{C}$ ages of 10 Yamato and Allan Hills meteorites: Proc Natl Inst Polar Research Symp Antartic Meteorites, 1, p 224-230, NIPR, Tokyo. 
Boeckl, R, 1972, Terrestrial age of nineteen stony meteorites derived from their radiocarbon content: Nature, v 236, p 25-26.

Born, W and Begemann, F, 1975, ${ }^{14} \mathrm{C}_{-}{ }^{39} \mathrm{Ar}_{\mathrm{me}}$ correlations in chondrites and their preatmospheric size: Earth Planetary Sci Letters, v 25, p 159-169.

Brown, R M, Andrews, H R, Ball, G C, Burn, N, Imahori, Y, Milton J C D and Fireman, E $\mathrm{L}, 1984,{ }^{14} \mathrm{C}$ content of ten meteorites measured by Tandem Accelerator Mass Spectrometry: Earth Planetary Sci Letters, v 67, p 1-8.

Desmarais, D J, 1983, Light element geochemistry and spallogenesis in lunar rocks: Geochim et Cosmochim Acta, v 47, p 1769-1781.

Fireman, E L, 1978, Carbon-14 in lunar soil and in meteorites: Proc Lunar Planet Sci conf, 9th, p $1647-1654$

1979, ${ }^{14} \mathrm{C}$ and ${ }^{39} \mathrm{Ar}$ abundances in Allan Hills meteorites: Proc Lunar Planet Sci conf, 10th, p 1053-1060.

1983, Carbon-14 ages of Antarctic meteorites (abs), in Lunar and planetary science XIV: Houston, Lunar \& Planetary Inst, p 195-196.

Fireman, E L, DeFelice, J and D'Amico, J, 1976, The abundances of ${ }^{3} \mathrm{H}$ and ${ }^{14} \mathrm{C}$ in the solar wind: Earth Planetary Sci Letters, v 32, p 185-190.

Freundel, M, Schultz, L and Reedy, R C, 1986, Terrestrial ${ }^{81} \mathrm{Kr}-\mathrm{Kr}$ ages of Antarctic meteorites: Geochim et Cosmochim Acta, v 50, p 2663-2673.

Goel, P S and Kohman, T, 1962, Cosmogenic carbon-14 in meteorites and terrestrial ages of "finds" and craters: Science, v 136, p 875-877.

Jull, A J T and Donahue, D J, 1988, Terrestrial age of the Antarctic shergottite, EETA 79001: Geochimica et Cosmochim Acta, v 52, p 1309-1311.

Jull, A J T, Donahue, D J and Linick, T W, 1989, Carbon-14 levels in recently fallen and in Antarctic meteorites: Geochim et Cosmochim Acta, in press.

Jull, A J T, Donahue, D J, Zabel, T H and Fireman, E L, 1984, Carbon-14 ages of Antarctic meteorites with accelerator and small-volume counting techniques: Jour Geophys Research, v 89, p C239-235.

Lal, D, 1987, Cosmogenic nuclides produced in-situ in terrestrial solids: Nuclear Instruments \& Methods, v B29, p 238-245.

Lal, D, Nishiizumi and J R Arnold, 1987, In-situ cosmogenic ${ }^{3} \mathrm{He},{ }^{14} \mathrm{C}$ and ${ }^{10} \mathrm{Be}$ for determining the net accumulation and ablation rates of ice sheets: Jour Geophys Research 92, 49474952 .

Lal, D and Peters, B, 1967, Cosmic ray produced radioactivity on the earth, in Handbuch der Physik: Berlin, Springer-Verlag, 46, no. 2, p 551-612.

Leavy, B D, Phillips, F M, Elmore, D, Kubik, P W and Gladney, E, 1987. Measurement of cosmogenic ${ }^{36} \mathrm{Cl} / \mathrm{Cl}$ in young volcanic rockes: An application of accelerator mass spectrometry in geochronology: Nuclear Instruments \& Methods, v B29, p 246-250.

Linick, T W, Jull, A J T, Toolin, L J and Donahue, D J, 1986, Operation of the NSF-Arizona Accelerator Facility for Radioisotope Analysis and results from selected collaborative research projects, in Stuiver, $\mathrm{M}$ and $\mathrm{Kra}, \mathrm{R} \mathrm{S}$, eds, Internatl ${ }^{14} \mathrm{C}$ conf, 12 th, Proc: Radiocarbon, v 28, no. 2A, p 522-533.

Negendank, J F W, Mooser, F, Emmermann, R, Tobschall, H, Krawczyk, R and Werle, D, 1985, Geological and geochemical investigations on the Eastern Trans Mexican Volcanic Belt: Geofisica Internacl, v 24-4, p 477-575.

Phillips, F M, Leavy, B D, Jannik, N O, Elmore, D and Kubik, P W, 1986, The accumulation of cosmogenic chlorine-36 in rocks: a method for surface exposure dating: Science, v 231, p $41-43$.

Reedy, R C and Arnold, R J, 1972, Interaction of solar and galactic cosmic rays with the Moon: Jour Geophys Research, v 77, p 537-555.

Shea, M A, Smart, D F and Gentile, L C, 1987, Estimating cosmic ray vertical cutoff rigidities as a function of the Mcllwain L-parameter for different epochs of the geomagnetic field: Phys Earth Planetary Interiors, v 48, p 200-205.

Sinkankas, J, 1976, Gemstones of North America, vol II: New York, Van Nostrand Reinhold Co, p 212.

Slota, P J Jr, Jull, A J T, Linick, T W and Toolin, L J, 1987, Preparation of small samples for ${ }^{14} \mathrm{C}$ accelerator targets by catalytic reduction of CO: Radiocarbon, v 29 , no. 2, p 303-306.

Suess, H E and Wänke, H, 1962, Radiocarbon content and terrestrial age of twelve stony meteorites and one iron meteorite: Geochim et Cosmochim Acta, v 26, p 475-480.

Yokoyama, Y, Reyss, J L and Guichard, F, 1977, Production of radionuclides by cosmic rays at mountain altitudes: Earth Planetary Sci Letters, v 36, p 44-50. 